\title{
Et lille bidrag til »Den Store Krigs" kulturhistorie
}

Erik Kulavig [ph.d., lektor, Institut for Historie, Syddansk Universitet. Leder af Center for Koldkrigsforskning, kulavig@sdu.dk]

Resultatet af en krig afgøres i sidste instans af mængden og kvaliteten af våben og økonomisk styrke. ${ }^{1}$ Det er dog givet, at kultur og herunder soldaternes og officerernes verdensbilleder og opfattelse af fjenden også spiller en rolle. I denne artikel undersøges det, hvordan kombattanterne på Østfronten så på hinanden under Den Første Verdenskrig. Det konkluderes, at tyskerne også kulturelt var langt bedre rustet til krig end russerne.

Den 1. august 1914 erklærede Rusland krig mod Det Tyske Rige, og allerede samme dag løsnedes de første skud. Dette var indledningen på den akt af Den Første Verdenskrig, som Churchill rammende har betegnet som »The Unknown War«. Tyskerne havde besluttet at overvinde Frankrig, før man begav sig mod øst med det formål at undgå en tofrontskrig. Derfor var Østprøjsens fem hundrede kilometer lange grænse til Rusland kun nødtørftigt bemandet med den 8 . Arme under ledelse af Generaloberst Maximilian von Prittwitz. Der stod altså små to hundrede tusind mand over for en russisk hær på en lille halv million. Havde tsar Nikolaj II derfor øjnet en chance for en spektakulær sejr, der kunne understøtte hans skrantende regime, kunne man dårligt fortænke ham i det.

En anden ting, der måske gav ham blod på tanden var visheden om, at der var ofret store summer på moderniseringen af den russiske hær siden det forsmædelige nederlag til Japan små ti år forinden. Efter de første fægtninger lød det, at russerne snart ville sætte sig på hele Østprøjsen. Det varede dog ikke længe, før de to herrer, den 67-årige Paul von Hintenburg (1847-1934), der i 1914 blev udnævnt til øverstbefalende for den tyske hær på Østfronten, og i 1933 udpegedes af Hitler til rigspræsident, og den 49-årige Erich Ludendorff (1865-1937), der var tysk general og Hintenburgs højre hånd, fik vendt udviklingen. Den 30. august lykkedes det således Hintenburg at omringe den russiske hær, der var under ledelse af general Aleksandr Samsonov ved Tannenberg. Ved de efterfølgende kampe faldt der 120000 russere, og 90000 havnede i krigsfangenskab. På den tyske side var tallet kun 13000

\footnotetext{
${ }^{1}$ Artiklen, hvoraf dele har været publiceret i tidsskriftet Rubikon, Syddansk Universitet, 2014, bygger på tysk- og russisksprogede kilder fra de elektroniske arkiver: Europaeana (http:// www.europeana.eu/) og Russkaja Armija $v$ gody pervoj mirovoj vojny (http://www.grwar.ru/ manifest/manifest.html). 
faldne. De store tabstal blev typiske for en krig, hvor godt ni millioner skulle gå til. Typisk var det også, at russerne led langt de største tab (Kossert 2014). Det er blevet forklaret med, at moderniseringen af hæren endnu ikke var blevet bragt til ende, at der var for mange uduelige adelsønner i officerskorpset og endelig, at moralen $\mathrm{i}$ hæren allerede i udgangspunktet var lav.

I denne artikel vises det, at russerne heller ikke havde noget klart fjendebillede, hvilket i sig selv må have bidraget til nederlaget. Officererne, der for langt størstedelens vedkommende var rekrutteret fra den russiske adel, havde stor respekt og beundring for den tyske orden og militære tradition, og var måske i kulturel henseende tættere på tyskerne end på deres egne bondesoldater. Den russiske bondesoldat have kun vage forestillinger om tyskerne - de stumme som de kaldes på russisk $\left(n e m t s y^{2}\right)$ - men de regnede med at krigen hurtigt ville være oversået, og at de dernæst kunne vende tilbage til landsbyen, der var hovedkilden til deres selvforståelse og identitet. Der var således på russisk side ikke opbygget noget had til fjenden på forhånd. Forholdet ændrede sig i krigens løb, men langt vigtigere end det mobiliserende had til fjenden, var den tiltagende frygt for den »tyske krigsmaskine«, som ingen djævel kunne stille noget op imod. De russiske soldater kom med andre ord hurtigt i tvivl om, hvorfor de overhovedet var gået i krig, og der var ikke noget klart fjendebillede. På tysk side var man derimod fra begyndelsen på det rene med, at det drejede sig om, at få de russiske barbarer jaget tilbage, hvor de kom fra. Som det hed $\mathrm{i}$ en populær revyvise: \Zarendreck, Barbarendreck, Peitscht sie weg «. ${ }^{3}$ Fjendebilledet var med andre ord på plads (Kossert 2014).

\section{Fjendebilledet}

Selv om det ikke er kulturen, men mere hårdtslående årsager som mængden og styrken af våben, der afgør en krig, spiller officerernes og soldaternes opfattelse af fjenden en vigtig rolle for viljen til at lade sig mobilisere og senere for kampviljen. Hvis dette ikke var tilfældet, ville de krigsførende magter næppe anvende så store midler på den »psykologiske krigsførelse«. Noget firkantet kan man sige, at det gælder om at få fjenden til at fremstå som det modsatte af en selv: fjenden er grusom, dum, en kryster, voldelig og endelig en trussel for det gode, som jeg repræsenterer. Selvom det kan forekomme modsætningsfyldt gælder det samtidig om at holde fast ved, at fjenden trods alt kan besejres.

\section{Den tyske side}

I årene op til og under den store krig udkom en række mere eller mindre tynde hæfter af populærvidenskabeligt tilsnit, der forherligede krigen og det tyske folk og kultur. Når krigen, som man i disse og andre publikationer og i store dele af offentligheden anså for nødvendig og retfærdig, var overstået, skulle Tyskland føre de europæiske

\footnotetext{
${ }^{2}$ Russerne kaldte tyskerne for »de stumme« formodentlig fordi de ikke forstod et ord af, hvad de sagde.

${ }^{3} \gg$ Tsarudskud, Babarudskud skal piskes ud«.
} 
folk frem mod højere mål. Krigen havde desuden en rensende effekt, der skulle befri folket fra fredstidens småborgerlighed i form af: »Kleinigkeit, Zanksucht, Genusssucht, Tendenz zu Feigheit und Gleichgültigkeit « ${ }^{4}$ (Barelhako 1916: 53). Alle borgernes behov og rettigheder underkastes Magten, der på sin side retfærdiggøres, fordi den bruges i menneskehedens interesse. For dette garanterer, som det hedder, »vor store og ædle fører af det tyske folk, vores kejser«. Denne citeres for følgende sentens, der gør op med enhver form for demokrati eller folkestyre. Her regerer kejseren, der med sin person udtrykker folkets inderste ønsker og vilje: »Ich kenne keine Parteien mehr, ich kenne nur Deutsche ${ }^{5}$ (Barelhako 1916: 54). Krigen kan ikke sammenlignes med andre krige, men ses som et tidehverv: som et sejrstog for den germanske kultur, som Tyskland stod i spidsen for, og som skulle redde ikke bare Europa, men hele verden.

Det var således Tysklands kald at integrere de europæiske folk under sin myndige ledelse, men det var ikke alle folk, der var lige lette at integrere. Folkeslagene vest, syd og nord for Tyskland ville umiddelbart kunne komme med i »det germanske rige«, mens nationerne mod øst, her særligt russerne, generelt blev betegnet som »mongolske» og dermed fremmede for europæisk kultur. Den storrussiske elite havde ganske vist lagt en stor del af den mongolske arv bag sig, mens de russiske masser stadig var under stor indflydelse deraf såvel fysisk som psykisk. De var af udseende lavstammede, kraftige, med flade stumpnæser og brede kindben. De var underdanige og bar tålmodigt deres fattige og ufrie lod. Åndeligt stod de i stampe særligt på grund af et umådeholdent indtag af alkohol. De blev desuden beskrevet som lettroende og overtroiske, og følelse havde klart forrang for enhver form for logisk endsige højere tænkning. Den robuste krop og den åndelige træghed betød, at de kunne udholde selv de sværeste strabadser. De var generelt næstekærlige og gæstfrie, men det ses snarere som udtryk for en primitiv livsform end som et udtryk for kultur.

Lillerusserne eller ukrainerne og hviderusserne stod højere i hierarkiet end storrusserne. Det skyldes, at de havde haft tættere samkvem med germanerne. De blev beskrevet som højere, med finere træk, og så mente man, de var mere følsomme og gemytlige end storrusseren. Desuden havde de større trang til uafhængighed. Disse "germanske træk « mente man også at kunne finde hos polakkerne og særligt i de større byer (Barelhako 1916: 59-65).

Den franske og britiske kultur blev betegnet som »civilisation « og dermed signalerede man, at der var tale om kulturer i forfald. De blev beskrevet som materialistiske og hedonistiske, og kun et fast tysk lederskab i form af den tyske helhedskultur kunne frelse dem. I centrum den tyske kultur, mod vest civilisation og mod øst ukultur.

De tyske soldater og officerer, der blev sendt mod Øst under krigen, havde en klar forforståelse af, hvem de var oppe imod. Den udgjorde en fortolkningsramme,

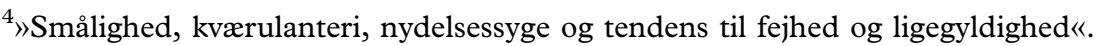

${ }^{5} \gg$ Jeg ved ikke længere, hvad partier er, jeg kender kun tyskere«.
} 


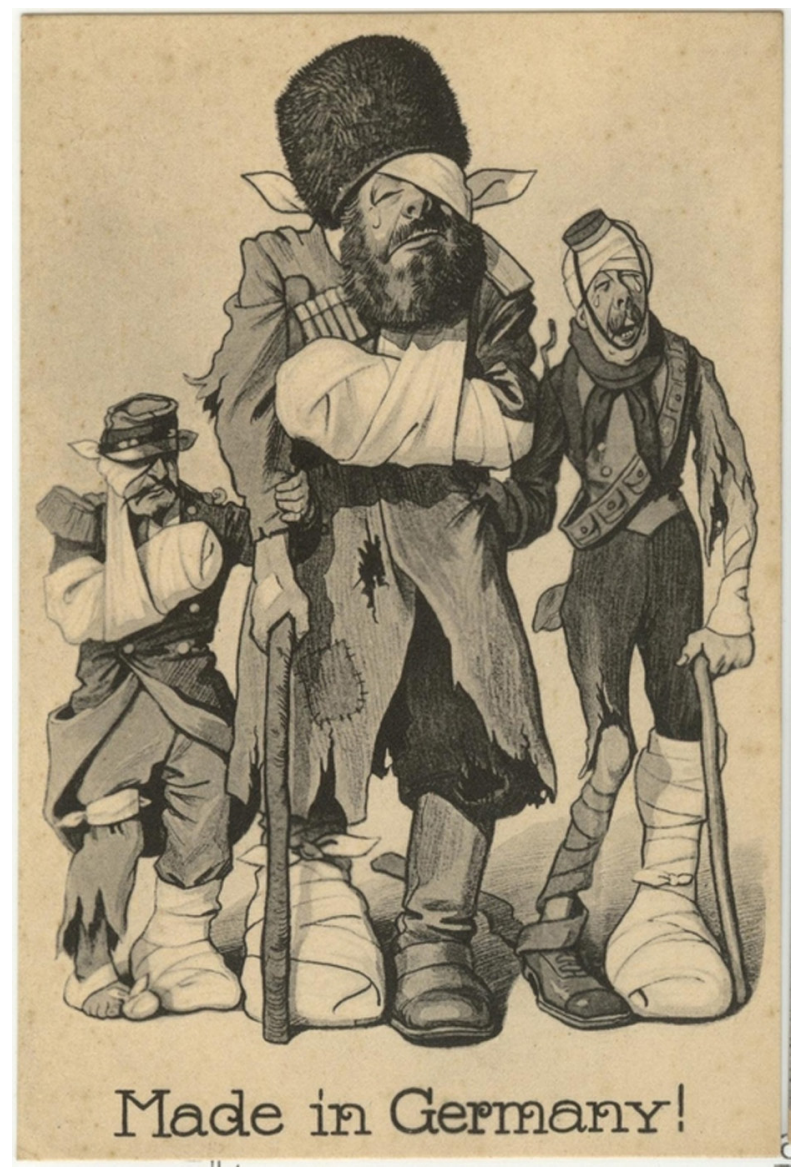

Billedtekst I: Denne karikatur afspejler den tyske opfattelse af deres hovedmodstandere. England og Frankrig var dekadente. Rusland stort, men alligevel en overkommelig fjende. Copyright: CC-BYSA 3.0 (se http://www.europeana1914-1918.eu/en/contributions/740). Tilgjengelig på https:// europeana1914-1918.s3.amazonaws.com/attachments/2984/740.2984.large.jpg?1304942356.

som de ikke umiddelbart kunne frigøre sig fra, og som de i krigens løb fik bekræftet i en grad, der gjorde, at hvad der først havde været forundring og medlidenhed over, at mennesker kunne leve i en sådan fattigdom og elendighed, snart udviklede sig til frygt og had. Tyskerne så i Øst snart ikke andet end krigens kaos, vold, grænseløse fattigdom, de allestedsnærværende og plagsomme lus og andet utøj og endelig de endeløse stepper, der i vinterens umenneskelige mørke og kulde, blev endnu mere truende. Dertil kom, at tabene i Øst var en tredjedel større end på Vestfronten og ikke mindst, at der ofte var tale om »gammeldags krig « mand mod mand med sabel og bajonet, hvilket var fremmed for tyskerne.

Det tyske udgangspunkt havde ellers været, at bringe den tyske orden og kultur til Øst. Dette fandt sit mest kontante udtryk i Ludendorffs militære mønsterstat: 


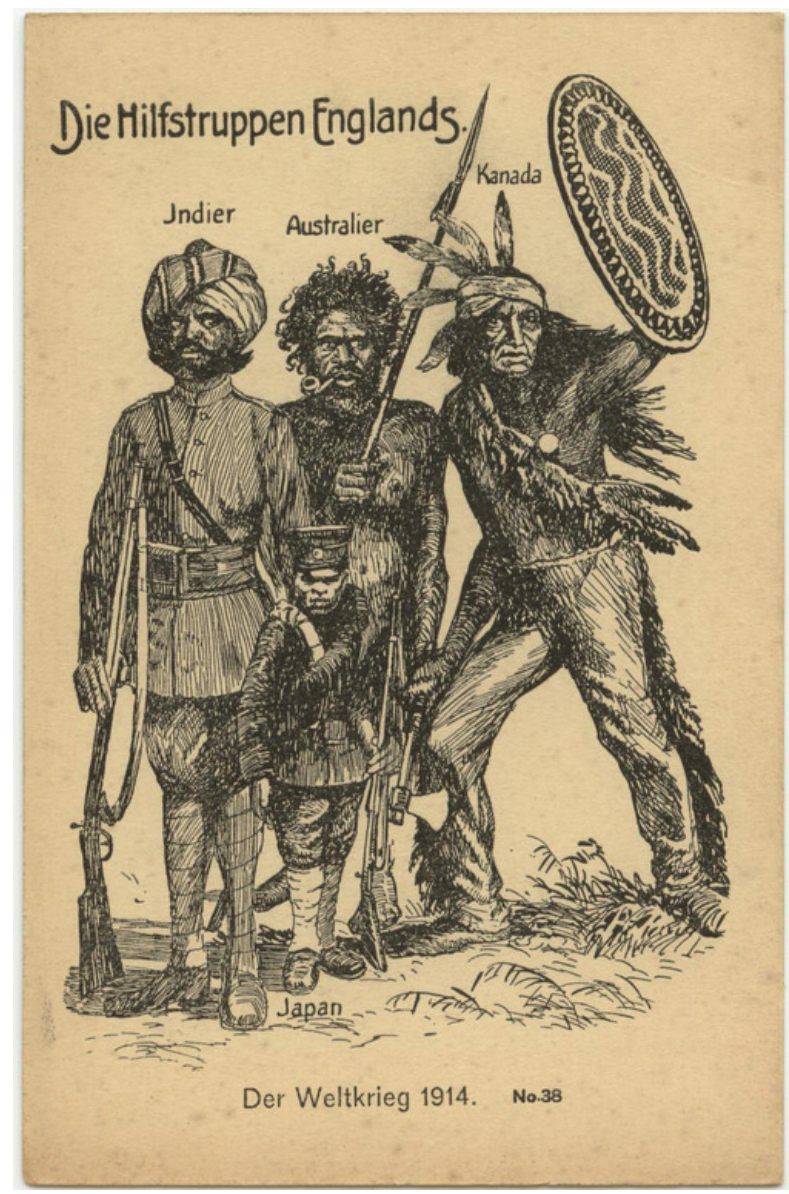

Billedtekst II: Tysk propaganda med stærkt racistiske undertoner. Udsagnet er en slet skjult forargelse over, at englænderne ville bygge deres hær på sådanne primitive folkeslag. Copyright: CCBY-SA 3.0 (se http://www.europeana1914-1918.eu/en/contributions/740). Tilgjengelig på https:// europeana1914-1918.s3.amazonaws.com/attachments/3004/740.3004.large.jpg?1304942391.

»Oberost«, der omfattede de tyske erobringer i Østeuropa og i Rusland. Dette blev af de besatte ofte og ikke uden grund opfattet som en »fortyskningspolitik «, som de modsatte sig så godt det var muligt. Denne tyske missionæridentitet måtte snart vige for en mere traditionel kolonipolitik, og efterhånden som krigen udviklede sig negativt for tyskerne på Vestfronten, hvor tyskerne til slut tabte krigen, udviklede der sig et veritabelt had til de primitive østfolk med deres kaos og snavs (Liulevicius 2005). Dette er blevet fortolket som et frø til nazisternes udryddelsespolitik: »Vil de ikke tage ved lære, må de fjernes«. Det er nærliggende, men man skal nok være varsom med at falde i den fælde, der hedder at beskrive historien baglæns. Listen over soldaternes og officerernes eksempler på den østlige ukultur er lang, men der var endnu hovedsaglig tale om kulturkritik og ikke racepolitik. 

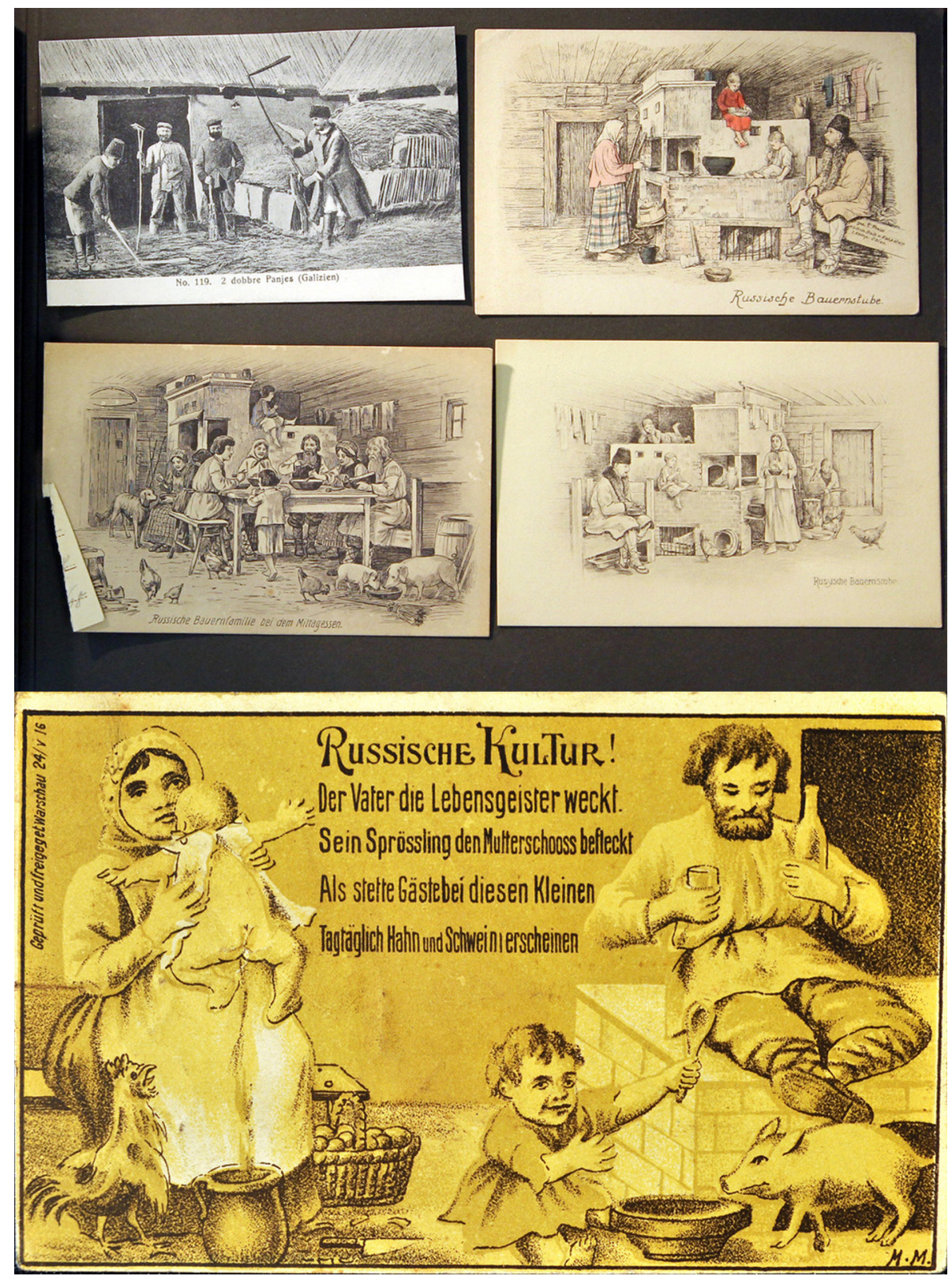

Billedtekst III og IV: To eksempler på tyske opfattelser af Rusland. Det første skildrer et primitivt og tilbagestående samfund, men russernes fremstilles som arbejdsomme og som familiemennesker $\mathrm{i}$ trygge og ryddelige hjem. Udsagnet går på, at der på trods af tilbageståenheden er kvaliteter at bygge på, hvis der gribes ind og rettes op af en imperiemagt. Det andet fremstiller bonden på niveau med dyrene, og der synes ikke at være levnet meget håb om mulighed for forandring. Copyright: CC-BYSA 3.0 (se http://www.europeana1914-1918.eu/en/contributions/1718 og http://www.europea na1914-1918.eu/en/contributions/1280). Tilgjengelig på https://europeana1914-1918.s3.amazo naws.com/attachments/19621/1718.19621.large.jpg?1310399932 og https://europeana1914-1918. s3.amazonaws.com/attachments/10539/1280.10539.large.jpg?1307350201. 
Den russiske side

Når man beskæftiger sig med krigens kulturhistorie i form af soldaternes og officerernes oplevelser, opfattelser og billeder af krigen og af fjenden, er det vigtigt, at man undgår at overgeneralisere og i stedet for virkeligheden kommer til at beskæftige sig med stereotypier. Et af de midler man kan tage i anvendelse er at fokusere på dynamikken og udviklingen i opfattelserne og i den forbindelse at undersøge, hvilken samfundsmæssig gruppe, socialt lag eller klasse man beskæftiger sig med. I det russiske tilfælde er der således stor forskel på, om man arbejder med tiden før de egentlige kamphandlinger, tiden under kampene eller tiden efter. Og der er, som vi skal se, stor forskel på, om vi bevæger os blandt officerer eller blandt almindelige soldater. De første havde som nævnt fortrinsvis adelig baggrund, mens de sidste næsten alle sammen kom fra landsbyerne. Et ikke ubetydeligt kontingent kom fra fabrikkerne, men der var de fleste førstegenerationsarbejdere uden dybere rødder i bykulturen.

Russernes generelle opfattelse af tyskerne i det 19. århundrede var en afslappet konstatering af, at her var en nabo med en anden livsform end russernes egen, og en naiv, men ikke aggressiv konstatering af, at det russiske folk nok var tyskerne overlegent (Kultysjev 2010: 131). Det var først i årene 1911-14, at den russiske statsmagt og den militære elite forstod, at Tyskland og Østrig-Ungarn var en fjende, men da stod det stadig skralt til med fjendebilledet. En af forklaringerne herpå er, at en stor del af den økonomiske, politiske og militære elite havde tyske rødder, og det gik helt op til Zaren, der var gift med den tyske prinsesse, Alexandra. Den kampagne, der blev iværksat, kom efter alt at dømme for sent til at ændre noget som helst. I værste fald - for den russiske sag - kom tyskerne nærmest til at fremstå som komiske og mere eller mindre harmløse. Det er med til at forklare den udbredte optimisme blandt høj og lav såvel i hæren som blandt almindelige borgere i begyndelse af krigen. En soldat skulle således have sagt: »Ret bajonetten mod hans mave, så ryger hænderne i vejret med det samme« (Kultysjev 2010: 155). Af soldaterbrevene fremgår det desuden, at alle regnede med en kort krig.

Omsvinget kom efter de første træfninger og specielt efter, at to russiske hære var blevet besejret i Østprøjsen. Nu lød det bredt, at tyskerne levede et bedre liv, at deres officerer var bedre end de russiske, at kun tyskerne kunne bygge fly. Alt sammen var det med til at skabe en skæbnesvanger opfattelse af, at tyskerne ikke kunne besejres. De russiske soldater var trænet til nærkamp mand mod mand og ikke som de tyske til moderne krig, hvor alt afgøres af mængden og størrelsen af våben. Bajonet og sværd mod artilleri og luftvåben, kunne de russiske soldater snart indse, var dømt til tab. Det hed i den forbindelse: »(...) tyskerne har ikke så store tab som os, fordi de gør alt med omtanke, mens vi er formørkede (...)« (Kultysjev 2010: 136). Om de tyske soldaters forhold, skriver en russiske soldat: »(. . ) de lever godt de djævle. I deres skyttegrave og deres kvarterer er der rent, varmt og lyst. Maden er som på en restaurant. Hver soldat har sin skål, to tallerkener, sølvske, gaffel, kniv (...). I flaskerne dyre vine og primus til at varme suppen« (Kultysjev 2010: 136). Dette fortæller sikkert ikke så meget om tyskernes reelle situation, men mere om den russiske og om det russiske mismod. 
Det samme gør sig formodentlig gældende i forbindelse med billedet af den tyske soldat: »Tysken er mæt, har gode sko, er velklædt, soigneret og i godt humør«. Der er ikke længere nogen vittigheder om tyske krystere. Nu hedder det: »Den tyske soldat er god og hård «. Mange taler om »den tyske maskine«. Tyskeren er desuden klog og snedig. Det er ikke ubetinget et positivt tegn, fordi især det sidste i russisk sammenhæng forbindes med kynisme og umenneskelighed. Når det gælder forholdet mellem officerer og menige er beskrivelserne ubetinget positive. Det fremgår af dette uddrag af en limerick: »De spiller musik for dem, os skælder de ud med eder og forbandelser, tyskerne trykker hinanden i hænderne, vi får nogen på trynen « (Kultysjev 2010: 140). Tyskerne absolutte overlegenhed fremgår af de mange stærkt beundrende skildringer af tyske bønders effektivitet og høje kultur i øvrigt: »(...)giv den tyske bonde vores sortjord, så vil han brødføde hele verden « (ibid.). Efterhånden som krigen skrider frem og kendskabet til tyskerne bliver bedre gennem forbrødringer ved fronten, tyske krigsfanger og sårede lyder der også mere realistiske vurderinger så som: »(...) de er ligesom os, begge er vi uden skyld i det her (...)« (ibid.).

For de menige soldaters vedkommende kan man således tale om tre faser $\mathrm{i}$ udviklingen af fjendebilledet. I den første fase fremtræder tysken som en lidt latterlig figur, som russerne snart skal få bugt med. Den anden fase, der indledes med de store nederlag i Østprøjsen, kendetegnes af opfattelsen af tyskerne som den uovervindelige krigsmaskine. I den tredje fase høres mest samme røster som i den anden, men også: tyskerne er mennesker lige som os på trods af alt.

Om de russiske officerer er det blevet sagt, at de ikke have noget fjendebillede, men et billede af modstanderen. Dermed signaleres, at det ikke var negativt. Snarere tvært imod kunne man sige. Det hang som nævnt sammen med, at mange af officererne var af tysk afstamning, at de have tysk familie og slægtninge, hvilket som bekendt også gialdt landets overhoved, tsar Nikolaj II, der var tysk gift. Der var således en udbredt respekt for de tyske sejre, og sorg over højtstående tyske officerers død. Den russiske general A.A. Brusjilov skulle have udtalt: »Den tyske soldat har som det tyske folk fortjent al mulig respekt« (Kultysjev 2010: 144). De russiske officerer var begejstrede ikke alene for, hvad de så, som den tyske hærs høje kultur, men også for den kultur, de stiftede bekendtskab med i de tyske landsbyer og byer i Østprøjsen. Bøndernes produktivitet og bøndergårdenes gode stand var ikke noget, de var vant til at se. Officerernes begejstring for det tyske, skærpede foragten for det russiske. De russiske nederlag blev i stigende omfang forklaret med de russiske soldaters mangel på orden og disciplin. Omvendt begyndte soldaterne at forklare nederlagene med officerernes tyskvenlighed.

\section{For Gud, tsaren og fædrelandet}

Det store flertal af de russiske soldater var enten bønder eller førstegenerationsarbejdere, og man har derfor ofte forbundet mentaliteten hos de russiske tropper med den russiske landsby. De konstituerende elementer var en fatalistisk opfattelse af at Gud og tsaren styrede verden, og at bonden måtte underkaste sig deres vilje, at arbejdet og dyrkelsen af den fælles jord var det centrale i tilværelsen, og at 
landsbyfællesskabet var såvel en forpligtelse som en beskyttelse af den enkelte. Der er således belæg for, at den brede befolkning lod sig gribe af patriotisk begejstring, da krigen blev erklæret. Herom vidner, at der ikke var nogen strejker i juli-december 1914, og endelig at bønder og arbejdere villigt lod sig mobilisere. Aviserne var fulde af gode historier om folkets patriotiske sindelag, men der var også fra begyndelsen et anarkistisk element, der blev mere fremtrædende, som krigen skred frem. Der tænkes her især på de traditionelle drukgilder, der spontant blev organiseret i forbindelse med soldaternes afgang fra landsbyerne og under transporterne til de militære forlægninger. Det udartede sig ikke sjældent til veritable orgier og pogromer med voldtægter og storm på butikker og lagre, hvor man vidste, at der var alkohol.

Myndighederne måtte ofte sætte politi og tropper ind for at få gemytterne dæmpet. Når de endelig kom i trøjen, hed det imidlertid: »at de var mere stille end vand lavere end græsset «. (Kultysjev 2010: 111). Erindringer og breve vidner om, at de især var de unge, der var ivrige efter at komme i krig, og at ønsket i lige høj grad var båret af en længsel efter at komme bort fra en ofte trøstesløs tilværelse som af patriotisme. For de mere modne familiefædre var der fra begyndelse en udbredt bekymring for, hvem der skulle klare dagen og vejen og få høsten i hus, nu da de måtte drage i krig.

Der er næppe grund til at tvivle på, at »Gud, tsar og fædreland « spillede en konstruktiv rolle for mobiliseringen til den russiske hær. Men det er lige så klart, at de tre elementer mistede kraft, efterhånden som krigen trak ud. Mange begyndte således at tvivle på Guds autoritet. En bonde skrev således: »Har Gud brug for alt det? Hvorfor har han så påbudt os ikke at slå ihjel?«. Endelig var der også vidnesbyrd om, at bøndernes patriotisme var så konkret, at da man ikke længere følte, at man sloges for at forsvare sine nærmeste, marken, konen og børnene blev tilbøjelig til at nedlægge våbnene (Kultysjev 2010: 121).

De unge uprøvede officerer var begejstrede for udsigten til krig, mens de mere erfarne var stærkt bekymrede. Et eksempel på det sidste var general P.N. Krasnov, der mente, at den russiske hær hverken ville eller kunne besejre den tyske hær (Kultysjev 2010: 90). Et eksempel på det første finder vi hos den unge officer, F.I. Eliseev, der skrev: »Alle er glade (...) vi er helt ind i sjælen glade for, at vi skal i krig« (Kultysjev 2010: 93).

Officererne havde et kodeks, der havde mere tilfældes med riddertiden end med moderne krig. Det hed for eksempel at man kun gik i krig mod soldater og ikke mod civile, at fjenden skulle nedkæmpes i ærlig kamp, at man ikke måtte slå en fjende, der var forsvarsløs, at de sårede skulle behandles, og at fanger skulle behandles med respekt. Disse gode regler blev ikke overholdt, men måske kan de forklare, at næsten alle officerer fra krigens begyndelse gik til i løbet af det første halvandet år (Kultysjev 2010: 98).

Efter to års krig var der ikke længere nogen begejstring at spore. Underofficeren A.A. Upornikovs beretning var således typisk: »Da jeg gik i krig, troede jeg, at der ventede mig store udfordringer, hvor heltemod og frygtesløshed ville være nødvendigt. I den virkelige krig er der imidlertid ingen poesi. Et batteri er en dødsfabrik og intet andet« (Kultysjev 2010: 99). 
Soldaterne gik i krig for Gud og for tsaren, men da fjenden viste sig uovervindelig, og da afstanden til egne officerer øgedes, vendte stemningen. Hertil bidrog naturligvis også bolsjevikkernes propaganda ved fronten, og ikke mindst de rettighederne soldaterne fik i forbindelse med den såkaldte »Ordre nr. 1《, der gav soldatersovjetterne stor magt. Deserteringer og åben modstand mod og drab på egne officerer tog til.

\section{Afslutning}

Vi har set, at tyskerne ikke alene var bedre rustet til krig end russerne, når det gjaldt materiel, strategi og disciplin, men også, når det gjaldt et fjendebillede, der skulle styrke kampviljen i egne rækker. Tyskerne havde allerede før krigen udråbt sig selv som kaldet til at redde Europa ved at indtage førerskabet. Storbritannien og Frankrig var slået ind på en dekadent kurs og var således på kulturel tilbagegang, mens Østeuropa og Rusland var tilbagestående kulturer, som med Tysklands hjælp kunne føres frem et højere stade. Da dette mislykkedes fandt der et skred sted i »fjendebilledet « fra et kulturproblem til et raceproblem, og dermed var var frøet til nazisternes racepolitik måske blevet sået. Denne proces blev tilskyndet af tyskernes nederlag i krigen på Vestfronten og bitterheden over at måtte trække sig på Østfronten, hvor krigen egentlig var vundet.

Russerne havde ikke noget fikst og færdigt fjendebillede, der kunne operationaliseres i forbindelse med krigen. Officererne var i mange henseender tættere på de tyske idealer end på det russiske folk. I det samme folk udviklede der sig med krigens gang et fjendebillede, der i stedet for at opildne til kamp styrkede defaitismen. Den tyske hær blev i stigende omfang opfattet som en krigsmaskine, som intet menneske kunne stille noget op imod.

\section{Litteratur}

Barelhako (1916) Der Weltkrieg 1914/15 als Siegeszug der germanischen Kultur, der Aufstieg der deutschen Kultur. Berlin: Faßhauer Staatsbibliothek zu Berlin - Preußischer Kulturbesitz, Deutschland.

Europaeana. Tilgjengelig på www.europeana.eu. Lesedato 26. oktober 2016. [Meget omfattende samling af dokumenter, der er tilgængelige via nævnte netadresse.]

Kossert, Andread (2014). »Der Mythos von Tannenberg«. Die Zeit 13. februar. Tilgjengelig på www.zeit.de/ 2014/08/erster-weltkrieg-ostpreussen. Lesedato 26. oktober 2016.

Kultysjev, P.G. (2010) Russkaja Armija v Pervoj Mirovoj Vojne, Istoriko-antropolitjeskij aspekt. Rostov na Donu: Pedagogitjeskij Institut, Juzjnogo Federalnogo Universiteta. [Historisk kandidatspeciale, der undersøger den russiske side af krigen og med mange nyttige henvisninger til arkiver og dokumenter.]

Liulevicius, Vejas Gabriel (2005) Warland on the Eastern Front. Cambridge: Cambridge University Press. [Fremragende kulturhistorisk analyse af tyskernes krig på Østfronten under Den Store Krig.]

Russkaja Armija v gody pervoj mirovoj vojny. Tilgjengelig på www.grwar.ru/manifest/manifest.html. Lesedato 26. oktober 2016. [Værdifuld samling af allehånde russisksprogede kilder til Den Første Verdenskrigs historie: Soldaterbreve, erindringer, politiske traktater, afhandlinger etc. Alt sammen tilgængeligt på ovenstående netadresse.] 